\title{
EFFECTIVENESS OF GROUP COUNSELLING FOR SMOKING CESSATION IN HOSPITAL STAFF
}

\author{
A. Schoonis, RN, G. Celis, RN, W. Wuyts, PhD, V. Lemaigre, MA, PhD and K. Nackaerts, MD, PhD
}

The Allied Respiratory Professionals Congress Travel Grants, sponsored by ResMed

Pneumology Division, University Hospitals Leuven, Belgium

WINNING ABSTRACT: Smoking prevalence among hospital staff is still considerable. It is well known that smoking cessation is difficult to establish without any help. Group counselling is effective for smoking cessation. In 2004, therefore, we decided to offer group counselling for smoking cessation to our hospital staff.

(1) To assess the efficacy of group counselling given by a multidisciplinary team of healthcare professionals.

(2) To determine the quit rate after group counselling in hospital staff.

The program is based on 10 group sessions of 90 min each. Each group contains a maximum of 16 participants. The group sessions were led by a nurse specialized in smoking cessation and consisted of education and behavioural interventions provided by health care professionals (respiratory physician, psychologist and a dietician). To improve smoking cessation motivation, spirometry (FEV1 and FVC) and exhaled CO were measured both at the start and at the end of the group counselling.

In total, 38 participants of 3 different groups entered group counselling. The mean age was 48 years, and $71 \%$ was female. They smoked an average of 20 cigarettes per day. Based on exhaled CO measurements and self-reports, smoking cessation, the quit rates after 6 months, 1 year and 2 years were, 27/35 (77\%), 25/35 (72\%) and 23/35 (66\%), respectively.

Group counselling program on smoking cessation in hospital staff based on 10 group sessions was able to induce a remarkably high amount of quitters. The hospital setting offered the opportunity to meet the group participants frequently afterwards, what might have helped in keeping the quitting results at about the same level, even after 2 years' follow-up.

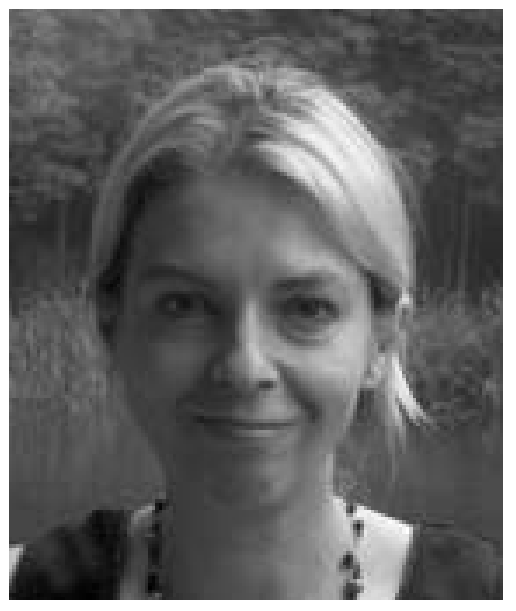

Annemie Schoonis

Pneumology Division, University Hospitals Leuven, Leuven, Belgium

\section{MY JOB AND THE UNIT IN WHICH I WORK}

I work as a head nurse on one of the respiratory units at the University Hospitals of Leuven (Leuven, Belgium). One unit, with 28 beds, specialises in lung transplantation, pulmonary hypertension and chronic obstructive pulmonary disease. Every healthcare programme has its own medical expert and clinical nurse specialist. Under my supervision there are 28 nurses, two

STATEMENT OF INTEREST: A. Schoonis is involved in smoking cessation programmes in fitness centres and health clubs that are sponsored by Novartis (Belgium) and the Flemish Society for Respiratory Care and Treatment of Tuberculosis (Brussels, Belgium). care-takers and four logistics employees. In 2001, the European Respiratory Society (ERS) Congress gave me the inspiration to create a Belgian Society of Respiratory Nurses as an ad hoc working group, together with our Belgian Society of Respiratory Physicians [1]. Every December, a symposium is held about a hot topic, such as inhalation therapy (2004), smoking cessation (2005) and oxygen therapy (2006). This year the topic was lung cancer.

In 2004, I met Prof. Fagerström in Glasgow at the ERS Congress. He helped me to detect smoking behaviour in lung transplant patients. He was our invited speaker in Ostend (2005) during a symposium about smoking cessation. This was the start-up of our teaching programme for smoking patients hospitalised in the respiratory wards.

The teaching programme for smoking hospitalised patients started with a systematic assessment of smoking behaviour in associated hospitals. From these assessments, several abstracts were submitted to the 2006 ERS Congress in Munich [2-4].

In 2002, we started a smoking cessation programme for motivated smokers, in collaboration with a Respiratory

TABLE 1 Characteristics of the 3 smokers groups

\begin{tabular}{lcccc} 
& Group 1 & Group 2 & Group 3 & Total \\
\hline Start & $03 / 05 / 2004$ & $12 / 10 / 2004$ & $03 / 10 / 2005$ & \\
$\mathbf{N}$ (male/female) & $16(5 / 11)$ & $14(5 / 9)$ & $8(0 / 8)$ & $38(10 / 28)$ \\
Mean age yrs & 47 & 43 & 53 & 48 \\
Exhaled CO ppm & 15.56 & 10.53 & 27.00 & 17.69 \\
\hline
\end{tabular}




\begin{tabular}{|c|c|c|c|c|}
\hline Smoking hab & & & & \\
\hline & Group 1 & Group 2 & Group 3 & Total \\
\hline Cigarettes/day & 20 & 21 & 20 & 20 \\
\hline Pack-yrs & 21.72 & 16.19 & 16.18 & 18.47 \\
\hline FTND & 5 & 5 & 6 & 6 \\
\hline Mean age at starting smoking & 15 & 17 & 16 & 16 \\
\hline
\end{tabular}

Physician, Wim Wuyts and the Catholic Public Health Insurance Company (Limburg, Belgium).

The intervention existed of group counselling: 10 meetings of $2 \mathrm{~h}$ duration each. Sessions were held during a 6-week period and led by well-trained facilitators. In each session, feelings about quitting were discussed, in addition to smoking-related topics, such as health effects, relaxation and nutrition. Every year a follow-up meeting was organised.

Participants were asked to fill in a Fagerström Nicotine Dependency Test and to perform spirometry before and after quitting. The course was evaluated every 6 months and results were validated by self-reported abstinence and by measuring exhaled carbon monoxide (PICO Smokerlyser system; Bedfont, Rochester, UK).

The number of quitters was as follows. After 1 yr: $133(36 \%)$ out of 368; after 2 yrs: 54 (35\%) out of 154; after 3 yrs: 21 (32\%)

\begin{tabular}{lcccc} 
TABLE 3 Quit rates & & & & \\
& Group 1 & Group 2 & Group 3 & Total \\
\hline $\begin{array}{l}\text { After } \mathbf{1 0} \text { sessions } \\
\text { (male/female) }\end{array}$ & $14(5 / 9)$ & $13(5 / 8)$ & $8(0 / 8)$ & $35(10 / 25) 92 \%$ \\
$\begin{array}{c}\text { After } \mathbf{6} \text { months } \\
\text { (male/female) }\end{array}$ & 11 & 10 & 6 & $27(77 \%)$ \\
$\begin{array}{c}\text { After } \mathbf{1} \text { year (male/female) } \\
\text { After } \mathbf{2} \text { years (male/female) }\end{array}$ & 10 & 10 & 5 & $25(72 \%)$ \\
\hline & 10 & 10 & 3 & $23(66 \%)$ \\
\hline
\end{tabular}

out of 66. After 2 and 3 yrs, only part of the original group could be approached for evaluation.

In 2004, under supervision of Prof. Nackaerts, a respiratory physician, we implemented this group counselling programme in our hospital for hospital staff. The results of this programme were very positive and stimulating. Therefore, we submitted our abstract to Group 9.3 for the 2007 ERS Congress.

We implemented a smoking cessation programme for the overall hospital staff and also for hospitalised patients. Two specialised smoking cessation nurses provided advice and individual training for the hospital staff as well as bedside education of the patients.

Based on the conclusions of my abstract, I hope to improve the smoking cessation results of both hospital staff and of hospitalised patients.

I would like to thank my nurse team e650 and my doctors (Prof. M. Decramer, Prof. G. Verleden, Prof. M. Delcroix, Prof. K. Nackaerts, Prof. L. Dupont and Prof. W. Wuyts) and also the members of our working group on smoking cessation (C. Lodewijckx, J. De Bent, M. Peys, V. Lemaigre, G. Celis, H. Vanderschelde, S. Mondelaers and K. Philippaerts) for their continuous support to fight against tobacco and its related disorders.

\section{REFERENCES}

1 Belgian Society of Respiratory Nurses (BVPV). Smoking behaviour in patients hospitalised in Belgian Respiratory Wards. Unpublished Survey. www.bvpv-sbip.be/algemene_ info.htm Date last updated: March 17, 2008.

2 Schoonis A, Cuvillier N, Lodewijckx C, Bouckaert B, Verleden GM. Comparison of carbon monoxide (CO) monitoring to urine cotinine (COT) analysis to detect tobacco use in lung transplant recipients. Eur Respir J 2006; 28: Suppl. 50, 133s.

3 Schuermans D, Lodewijckx C, Deschepper I, et al. Counselling for smoking cessation needed in one third of hospitalised respiratory patients. Eur Respir J 2006; 28: Suppl. 50, 838s.

4 Wuyts WA, Schoonis A, Schrijnemakers J. Smoking cessation, a change in life, for life? Results of a smoking cessation program organised by a public health insurance company. Eur Respir J 2006; 28: Suppl. 50, 392s. 